\title{
Evaluation of chronic respiratory effects in the potato processing industry: indications of a healthy worker effect?
}

\author{
Jan-Paul Zock, Dick Heederik, Gert Doekes
}

\begin{abstract}
Objective-To investigate the occurrence of chronic respiratory effects of exposure to organic dust in the potato processing industry.

Methods-Self reported chronic respiratory symptoms and spirometric lung function were assessed in a cross sectional study among 135 potato processing workers. A comprehensive study of current exposure to dust, endotoxin, and potato antigens had been performed previously. Workers were grouped into low and high exposure categories for each of the three exposure indices. Relations between exposure concentrations and respiratory health variables were investigated either by calculating prevalence rate ratios or by performing linear regression analyses. Atopy was assessed by measuring total immunoglobulin E (IgE) and specific IgE to five common aeroallergens in serum samples of workers.
\end{abstract}

Results-Evident relations between current exposure indices and respiratory health in the entire group were not found. Workers employed $\leqslant 5$ years showed a twofold higher prevalence of respiratory symptoms, lower lung function, and higher endotoxin exposure than workers employed for $>5$ years. Also, atopy was more prevalent in workers employed $\leqslant 5$ years. After stratification for duration of employment, negative effects of endotoxin on lung function among workers employed $\leqslant 5$ years were suggested.

Conclusions-This study does not show chronic respiratory effects of exposure to organic dust in the potato processing industry, despite the fact that the levels of exposure to endotoxin found in this industry have been reported to be associated with decreases in lung function in other occupational settings. A likely explanation for not detecting apparent effects might be that many symptomatic workers drop out of this industry a few years after starting the job, suggesting a healthy worker effect. (Occup Environ Med 1998;55:823-827)

Keywords: respiratory disease; organic dust; endotoxin; healthy worker effect

In the potato processing industry high exposures to airborne dust, viable micro-organisms, and endotoxin have been found. ${ }^{1-3}$ In the same studies a prevalence of respiratory symptoms of
$16 \%-46 \%$ has been reported, predominantly shortness of breath and chest tightness. Flulike symptoms - such as malaise and muscular pains - even leading to sick leave, have been reported in departments with an exceptionally high microbial exposure. These respiratory and systemic disorders were consistent with the so called organic dust toxic syndrome (ODTS)..$^{4-7}$ In our own surveys in the potato processing industry, immunoglobulin G (IgG) specifically responded to airborne dust. This seemed to be related to exposure to airborne antigens. ${ }^{8} \mathrm{~A}$ type III allergic reaction, however, was not likely because this response was predominantly specific production of IgG $_{4}$ antibodies. ${ }^{9}$ This was not related to the presence of symptoms.

In the same studies bacterial endotoxin seemed to be an important constituent of the organic dust mixture, ${ }^{23}$ and significant associations between exposure to endotoxins and lung function changes across the shift were found. ${ }^{10}$ Thus it was concluded that endotoxin played a part in the aetiology of acute respiratory effects, and the question arose whether the high exposure to endotoxins found might also be related to chronic respiratory health effects in this industry. Chronic respiratory health effects related to endotoxins have been described among cotton workers, ${ }^{11-13}$ pig farmers, ${ }^{14-16}$ and grain and animal feed workers. ${ }^{17}$ Reported effects in the these studies consisted of increased prevalences of bronchitis-like symptoms, increased non-specific bronchial hyperresponsiveness, and decrements in forced expiratory volume in one second $\left(\mathrm{FEV}_{1}\right)$ and other lung function variables. In several studies $^{111617}$ exposure to organic dust based on weight was less clearly related to outcomes of respiratory health than exposure to endotoxins.

This report focuses on a cross sectional analysis of chronic respiratory symptoms and respiratory function, and their relations with exposure to dust, endotoxin, and antigens in four potato processing plants. A description of the production process and detailed information on exposure can be found elsewhere. ${ }^{38}$

Subjects and methods

POPULATION AND QUESTIONNAIRE

The study population comprised 142 male workers from four plants of a large potato processing company. This industry is characterised by processing work from August to March. Consequently, workers are not exposed to organic dust during the other 4-5 months of the year. In this period, operators are employed in maintenance work which involves stripping 
down the plant and preparing it for the next season. A small percentage of the workers are only employed for processing work. There is a considerable amount of job rotation from year to year.

Workers completed a self administered questionnaire on occupational history in potato processing, smoking habits, and the Dutch version of a questionnaire on respiratory symptoms from the British Medical Research Council. ${ }^{18}$ Results of separate questions on respiratory symptoms were combined because of small numbers and expected clustering. Asthma symptoms were frequent wheezing (for more than 1 week during the past 2 years) or ever experienced attacks of chest tightness (asthma). Bronchitis symptoms were chronic cough or chronic phlegm (both during the past 2 years for at least 3 months almost daily), and shortness of breath (when walking at normal speed on flat ground).

LUNG FUNCTION

Forced expiratory lung function measurements were performed by 132 workers just before or at the beginning of the potato processing work (July-August 1992). Most workers were tested at the start of the afternoon shift. For practical reasons, however, 36 workers were tested after the morning shift, and 10 before the night shift.

Two Vicatest-5 dry rolling-seal spirometers (Jaeger, Breda, The Netherlands), calibrated before and after measurement sessions, were used by one of us and a trained assistant. The measurements and procedures including body temperature and pressure saturated with water vapour (BTPS), adjustments, and data selection were performed according to the recommendations of the European Community for Steel and Coal. ${ }^{19}$ The following variables were registered: forced vital capacity (FVC), forced expiratory volume in one second $\left(\mathrm{FEV}_{1}\right)$, maximal mid-expiratory flow (MMEF), and peak expiratory flow (PEF).

ATOPY

Blood serum samples were available from 125 workers; 109 workers were sampled both before and during the processing work. ${ }^{8}$ Total IgE as well as specific IgE to five common aeroallergens (house dust mite, grass pollen, birch pollen, cat dander and dog dander) were determined in all 234 serum samples as described by Doekes et $a l .{ }^{20}$ Workers were considered to be atopic if specific IgE to at least one allergen was detected, either before or during work. A second definition of atopy consisted of a total IgE concentration $\geqslant 100$ units $/ \mathrm{ml}$, either before or during work.

EXPOSURE ASSESSMENT

Results of personal exposure measurements have been described elsewhere. ${ }^{38}$ Briefly, 211 personal full shift inhalable dust exposure measurements were performed among 128 workers. Bacterial endotoxin and potato antigens were measured in dust extracts of 195 and 186 filter halves, respectively. For all three exposure indices large differences existed between plants and between job categories. A
Table 1 Respiratory health characteristics of 135 potato processing workers

\begin{tabular}{lrrr}
\hline & $n(\%)$ & Mean & Range \\
\hline Age (y) & & 40.1 & $22-58$ \\
Employment in potato & & 13.2 & $0-38$ \\
$\quad$ processing (y) & $103(76)$ & & \\
$>5$ & $84(62)$ & & \\
$>10$ & $56(41)$ & & \\
Smokers & $41(30)$ & & \\
Ex-smokers & $16(12)$ & & \\
Asthma symptoms & $10(7)$ & & \\
$\quad$ Frequent wheezing & $12(9)$ & & \\
Chest tightness & $12(9)$ & & \\
Bronchitis symptoms & $5(4)$ & & \\
$\quad$ Chronic cough & $5(4)$ & & \\
Chronic phlegm & $7(5)$ & & \\
Shortness of breath & $39(31)$ & & \\
Atopy (n=125): & $38(30)$ & & \\
$\quad$ Specific IgE & & \\
$\quad$ Total IgE $\geqslant 100$ units/ml & & \\
Lung function (\% of predicted; $n=113):$ & & \\
$\quad$ FVC & & 108 & $79-146$ \\
FEV & & $66-140$ \\
MMEF & & 85 & $28-174$ \\
PEF & & $64-189$ \\
\hline
\end{tabular}

job exposure matrix (JEM) was developed based on 27 categories of job by plant. The arithmetic mean exposure for each category was used as the exposure estimate for workers in each group. Thus, for each of the 142 workers in this study exposure to dust, endotoxin, and antigen was assessed on the basis of his plant and job category.

For each of the three exposure indices, workers were divided into low and high exposure categories with the medians of each distribution as the cut off points. Associations between dichotomised exposure and lung function were evaluated with multiple linear regression analyses with age, standing height, and number of pack-years smoked as explanatory covariables. Separate regression analyses were applied for each of the three exposure indices.

\section{Results}

Seven of the 142 workers ( $5 \%$ ) had incomplete data on respiratory health or job history and were therefore excluded from the analyses. Fifteen of the 132 workers who performed lung function tests $(11 \%)$ did not meet the criteria for data selection of the European Community for Steel and Coal, ${ }^{19}$ two workers were not white, and two had incomplete questionnaires. Workers with and without adequate lung function tests had similar prevalences of respiratory symptoms, and similar levels of exposure. All further lung function analyses were hence performed with data from 113 male white workers with complete data on respiratory health, smoking habits, and job history.

Table 2 Descriptive statistics of estimated ${ }^{\star}$ personal exposure to dust, endotoxin, and antigens among 135 potato processing workers

\begin{tabular}{lcclc}
\hline Exposure & AM & GM & Range & Median \\
\hline Dust $\left(\mathrm{mg} / \mathrm{m}^{3}\right)$ & 2.93 & 1.61 & $0.2-29$ & 1.55 \\
Endotoxin $\left(\mathrm{EU} / \mathrm{m}^{3}\right)$ & 990 & 449 & $23-8167$ & 406 \\
Antigens $\left(10^{3} \mathrm{RAU} / \mathrm{m}^{3}\right)$ & 10.7 & 2.48 & $0.04-170$ & 1.79
\end{tabular}

${ }^{\star}$ Each worker was given the arithmetic mean exposure of his plant specific job category, ${ }^{3}{ }^{8} 27$ categories were distinguished. $\mathrm{AM}=$ arithmetic mean; $\mathrm{GM}=$ geometric mean; $\mathrm{EU}=$ endotoxin units; RAU=relative antigen units. 
Table 3 Characteristics of the 135 potato processing workers, stratified by duration of employment

\begin{tabular}{|c|c|c|}
\hline & \multicolumn{2}{|c|}{ Duration of employment $(y)$} \\
\hline & $\leqslant 5$ & $>5$ \\
\hline ubjects (n) & $\begin{array}{l}32 \\
31.8\end{array}$ & $\begin{array}{c}103 \\
42.6\end{array}$ \\
\hline Age (mean (range)) & $(22-48)$ & $(25-58)^{\star}$ \\
\hline Smokers (n (\%)) & $12(38)$ & $44(43)$ \\
\hline Ex-smokers (n (\%)) & $6(19)$ & $35(34) \dagger$ \\
\hline Symptoms of asthma (n (\%)) & $7(22)$ & $9(8.7) \ddagger$ \\
\hline Symptoms of bronchitis (n (\%)) & $4(13)$ & $8(7.8)$ \\
\hline Specific IgE $(n=27+98)(n(\%))$ & $15(56)$ & $24(24) \S$ \\
\hline $\begin{array}{l}\text { Total IgE } \geqslant 100 \text { units } / \mathrm{ml} \\
\quad(\mathrm{n}=27+98)(\mathrm{n}(\%))\end{array}$ & $11(41)$ & $27(28)$ \\
\hline $\begin{array}{l}\text { Dust exposure: } \mathrm{GM}\left(\mathrm{mg} / \mathrm{m}^{3}\right) \\
\text { (mean) }\end{array}$ & 1.69 & 1.59 \\
\hline $\begin{array}{l}\text { Endotoxin exposure: GM } \\
\left(\mathrm{EU} / \mathrm{m}^{3}\right) \text { (mean) }\end{array}$ & 820 & $372 \uparrow$ \\
\hline $\begin{array}{l}\text { Antigen exposure: GM }\left(\times 10^{3}\right. \\
\left.\text { RAU } / \mathrm{m}^{3}\right) \text { (mean) }\end{array}$ & 3.48 & 2.24 \\
\hline $\left.\mathrm{FVC}^{2}\right)($ mean $)$ & 105 & $108^{\star \star}$ \\
\hline $\mathrm{FEV}_{1}($ mean) & 102 & 104 \\
\hline MMEF (mean) & 85 & 85 \\
\hline PEF (mean) & 113 & $123+\dagger$ \\
\hline
\end{tabular}

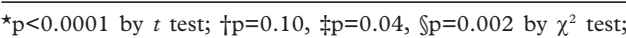
qp $=0.001,{ }^{\star \star} \mathrm{p}=0.09,+\dagger \mathrm{p}=0.03$ by $t$ test.

In table 1 demographic and respiratory health characteristics of the potato processing workers are presented. The overlap between the symptoms of asthma and bronchitis was limited; six out of 22 symptomatic workers had both sets of symptoms. Workers with symptoms of asthma were on average 36 years old, against 41 years among workers without asthmatic symptoms ( $\mathrm{p}=0.07$, by $t$ test). Mean ages were 37 and 40 years in the group of workers with and without symptoms of bronchitis. Most of the workers had been employed for $>10$ years. Five workers were newly employed in this industry, and five had been employed for only one year. Although both definitions of atopy showed a similar prevalence, in 33 of the 125 workers $(26 \%)$ the two definitions of atopy did not agree.

Descriptive statistics of the distributions of estimated exposure to dust, endotoxins, and antigens in 135 workers in table 2 indicated large ranges across the 27 categories. Estimated dust exposure did not correlate with endotoxin exposure (Pearson's $r$ between logarithms was $-0.11)$. Antigen exposure was significantly correlated with both dust $(r=0.24)$ and endotoxin exposure $(r=0.50)$. For each exposure index, workers were grouped into low and high categories with $50 \%$ as the cut off points. There was reasonable agreement between exposure categories of endotoxin and antigen: $63 \%$ of

Table 4 Relations between current exposure and lung function (multiple linear regression models for dichotomised exposure indices on lung function variables, with adjustment for age, standing height and number of pack-years smoked ${ }^{17}$ )

\begin{tabular}{lllll}
\hline & $F V C(l)$ & $F E V_{1}(l)$ & MMEF $(l / s)$ & PEF $(l / s)$ \\
\hline All (n=113): & $-0.06(0.11)$ & $+0.02(0.10)$ & $+0.09(0.22)$ & $+0.17(0.42)$ \\
$\quad$ High exposure to dust & $+0.18(0.12)$ & $+0.02(0.10)$ & $-0.29(0.23)$ & $-0.08(0.44)$ \\
High exposure to endotoxin & $+0.02(0.12)$ & $-0.03(0.10)$ & $-0.16(0.22)$ & $-0.16(0.43)$ \\
$\quad$ High exposure to antigen & $+0.02)$ & & \\
Employed $\leqslant 5$ y (n=24): & & & & \\
High exposure to dust & $-0.12(0.19)$ & $+0.03(0.20)$ & $+0.10(0.46)$ & $+1.25(0.85)$ \\
High exposure to endotoxin & $-0.05(0.18)$ & $-0.31(0.17)^{\star}$ & $-0.86(0.37) \dagger$ & $-0.50(0.81)$ \\
High exposure to antigen & $+0.01(0.19)$ & $+0.00(0.19)$ & $-0.13(0.43)$ & $+0.34(0.84)$ \\
\hline
\end{tabular}

${ }^{\star} \mathrm{p}=0.08$.

$\mathrm{tp}=0.03$.

Values are coefficients (SEM) which denote estimated differences in lung function between workers with high and low exposure. the workers were placed in the same category of exposure to endotoxin and antigen.

Consistent relations between current exposure and prevalence of respiratory symptoms could not be found. The use of current exposure estimates in chronic effect analyses might lead to misclassification because of the job rotation mentioned earlier. Therefore, an analysis was carried out with duration of exposure in potato processing. A remarkable finding was that respiratory symptoms were clearly less prevalent in workers who had been employed for $>5$ years in potato processing. This seemed to be true for symptoms of both asthma and bronchitis. Because of this finding, it was investigated whether other respiratory outcomes and possible determinants were also related to duration of employment (table 3 ). Lung function was higher in the group of workers employed $>5$ years. Atopy was more prevalent in workers employed for only a short time, and was most pronounced for specific IgE. It is known that prevalence of atopy decreases with increasing age. ${ }^{212}$ A higher prevalence of atopy in workers employed $\leqslant 5$ years was also noted when considering different age tertiles.

Exposure to endotoxin was on average twofold higher among short term workers. As a result, $63 \%$ of the workers employed $\leqslant 5$ years were in the high exposure to endotoxin group, against $44 \%$ of the workers employed $>5$ years. Average exposure to dust and antigen in the two groups showed the same pattern, but differences were smaller than found for endotoxin.

To account for the differences found between short term and long term workers, further analyses were performed after stratification for duration of employment (cut off point 5 years). Table 4 shows linear regression coefficients of exposure indices on lung function variables. For the entire group no consistent relations between current exposure and lung function could be noted. In the subset of workers employed $\leqslant 5$ years, however, indications for an adverse effect of exposure to endotoxins on lung function can be seen in table 4 . For exposure to dust and antigen the effects were not consistent. Regression coefficients in the group of workers employed $>5$ years ( $n=89$; results not shown) were similar to regression coefficients found in models with the entire population.

\section{Discussion}

In this study the respiratory health of potato processing workers relative to exposure to organic dust was investigated. Frequent wheeze was more prevalent in the study group (7\%) than among the non-exposed controls $(2 \%),{ }^{17}$ and was similar to that in office workers, ${ }^{23}$ animal feed workers, ${ }^{17}$ and pig farmers. ${ }^{14}{ }^{24}$ Prevalence of chest tightness ( $9 \%$ ) seemed to be higher than that found among controls $(6 \%)$, office workers $(7 \%)$, and animal feed workers ( $4 \%$ ), but was similar to that found among pig farmers. Endotoxin is a recognised risk factor for chronic bronchitis. ${ }^{111325}$ Nevertheless, the prevalence of chronic cough (4\%), indicative of 
bronchitis, was lower compared with the other populations mentioned $(5 \%-10 \%)$. Lung function was on average not lower than expected. Percentages of reference values were more or less the same as those found among pig farmers ${ }^{16}$ in whom a similar percentage smoked but clearly more were symptomatic $(48 \%)$.

Three indices of exposure to organic dust were considered: dust, endotoxin, and antigens based on weight. In a previous study we showed that a specific $\mathrm{IgG}_{4}$ response, which seemed to be related to exposure to airborne antigens, was not associated with the presence of respiratory symptoms. ${ }^{8}$ Thus, an adverse respiratory effect of antigen exposure was initially not likely. This was confirmed in the present study by the absence of apparent relations between exposure to antigens and respiratory health outcome.

There is strong evidence that endotoxin has acute and chronic health effects-such as decreased lung function and increased bronchial reactivity at levels encountered in this study. The levels found in this industry have been reported to be clearly associated with decreases in lung function in several other occupational settings. ${ }^{113-17}$ Contrary to expectations, we did not find clear cut chronic respiratory effects of exposure to endotoxin in the entire study population. Dust exposure was low in most departments of the plants studied. ${ }^{3}$ Moreover, in several studies among workers exposed to organic dusts it was shown that exposure to dust was less clearly related to chronic respiratory symptoms and lung function than exposure to endotoxin. ${ }^{15-17}$

Some reasons for not detecting relations can be considered. An important issue is the seasonal pattern of exposure to organic dust in this industry. This pattern is present in a few other industries, mostly related to agriculture, with seasonal work-such as sugar beet refinement. ${ }^{26}$ Little is known about chronic effects due to occupational exposures in these types of industries. It can be speculated that a few months of recovery time counters irreversible effects of exposure to organic dust.

Another problem in the design of our study might be the use of current exposure estimates for chronic effect analyses. When considering duration of employment as a crude cumulative exposure index, an effect seemed to be present because workers who had been employed for $>5$ years had less respiratory symptoms, a higher lung function, and less atopy. This apparent selection is suggestive of the healthy worker effect, as reported mostly in longitudinal studies. ${ }^{27} 28$ It can be speculated that symptomatic workers drop out of this industry after a few years. Also, a trend towards lower exposures to endotoxin in longer term workers was found, suggesting that job rotation also plays a part in this process. However, longitudinal data on respiratory health and employment in the potato processing industry are required to support this hypothesis. Unfortunately, our study in the potato processing industry has been ongoing for only a few years, and does not allow a proper investigation into drop out of workers.

An analytical approach to minimise the influence of the healthy worker effect is to con- sider exposure-response relations for various periods since first exposure. ${ }^{29}$ In the group of workers employed $\leqslant 5$ years, negative coefficients for exposure to endotoxins on lung function were indicative of adverse respiratory effects in this subgroup. However, the fact that this may partly reflect an acute effect related to endotoxins cannot be excluded.

Prevalence of atopy, defined as specific IgE to $\geqslant$ one out of five common aeroallergens, amounted to $31 \%$. This concords with $32 \%$ reported in a Dutch general population study among $1286 \mathrm{men}$, aged 20-70. ${ }^{21}$ Atopy was twofold more prevalent in workers employed $\leqslant 5$ years. This corroborates the health related selection already mentioned. From population studies it is known that prevalence of atopy decreases with increasing age. ${ }^{21} 22$ The difference in age, however, could only partly explain the difference in atopic prevalence between short term and long term employed workers. Interestingly, these findings are consistent with a longitudinal study among grain workers, ${ }^{30}$ in which atopic workers developed more respiratory symptoms after the start of employment, and more atopic than non-atopic workers dropped out of the grain industry. Total IgE is less clearly related to age, ${ }^{2122} 31$ and increased total IgE actually showed a smaller difference between short and long term workers.

We conclude that no chronic respiratory effects of exposure to organic dust in the current workforce in the potato processing industry have been found. Several findings in our study, however, strongly suggest that this might be at least partially due to the fact that symptomatic workers drop out of this industry within a few years of starting the job.

We thank the potato processing company for the study commission, and its workers for their cooperation. We acknowledge Anke Boumans for lung function testing, and Siegfried de Wind and Isabella van Schothorst for laboratory assistance.

1 Dutkiewicz J. Bacteria, fungi and endotoxin as potential agents of occupational hazard in a potato processing plant. Am f Ind Med 1994;25:43-6.

2 Hollander A, Heederik D, Kauffman H. Acute respiratory effects in the potato processing industry due to a bio-aerosol exposure. Occup Environ Med 1994;51:73-8.

3 Zock JP, Heederik D, Kromhout H. Exposure to dust, endotoxin, and micro-organsims in the potato processing industry. Ann Occup Hyg 1995;39:841-54.

4 doPico GA. Report on diseases. Am F Ind Med 1986;10: 261-5.

5 Donham KJ, Thorne PS. Agents in organic dust: criteria for a causal relationship. Am f Ind Med 1994;25:33-9.

Rask-Andersen A. Organic dust toxic syndrome among farmers. Br f Ind Med 1989;46:233-8.

7 Richerson HB. Unifying concepts underlying the effect of organic dust exposures. Am F Ind Med 1990;17:139-42.

8 Zock JP, Doekes G, Heederik D, et al. Airborne dust antigen exposure and specific IgG response in the potato exposure and specific IgG response in the pota
processing industry. Clin Exp Allergy 1996;26:542-8.

9 Van der Zee JS, Aalberse RC. The role of IgG. In: Lessof MH, Lee TH, Kemeny DM, eds. Allergy: an international MH, Lee TH, Kemeny DM, eds. Allergy: an in

10 Zock JP, Hollander A, Heederik D, et al. Acute lung function changes and low endotoxin exposures in the potato processing industry. Am F Ind Med 1998;33:384-91.

11 Kennedy SM, Christiani DC, Eisen EA, et al. Cotton dust and endotoxin exposure-response relationships in cotton textile workers. Am Rev Respir Dis 1987;135:194-200.

12 Rylander R, Bergström R. Bronchial reactivity among cotton workers in relation to dust and endotoxin exposure. Ann Occup Hyg 1993;37:57-63.

13 Sigsgaard T, Pedersen OF, Juul S, et al. Respiratory disorders and atopy in cotton, wool and other textile mill workers in Denmark. Am f Ind Med 1992;22:163-84.

14 Heederik D, Brouwer R, Biersteker K, et al. Relationship of airborne endotoxin and bacteria levels in pig farms with the lung function and respiratory symptoms of farmers. Int Arch Occup Environ Health 1991;62:595-601. 
15 Zejda JE, Barber E, Dosman JA, et al. Respiratory health status in swine producers relates to endotoxin exposure in the presence of low dust levels. F Occup Med 1994;36:4956.

16 Preller L, Heederik D, Boleij JSM, et al. Lung function and chronic respiratory symptoms of pig farmers: focus on exposure to endotoxins and ammonia and use of disinfectants. Occup Environ Med 1995;52:654-60

17 Smid T, Heederik D, Houba R, et al. Dust- and endotoxinrelated respiratory effects in the animal feed industry. $A m$ Rev Respir Dis 1992;146:1474-9.

18 Biersteker K, Dijk WH van, Eissens JBMF, et al. Ervaringen met geneeskundig onderzoek op CARA bij gemeentepersoneel te Rotterdam in 1970-1. Tijdschrift voor Sociale Geneeskunde 1974;52:158-62. (In Dutch, with a summary in English.)

19 Quanjer PhH, Tammeling GJ, Cotes JE, et al. Lung volumes and forced ventilatory flows. Eur Respir F 1993;6(suppl 16): 5-40.

20 Doekes G, Douwes J, Wouters I, et al. Enzyme immunoassays for total and allergen specific IgE in population noassays for total and allergen specific IgE
studies. Occup Environ Med 1996;53:63-70.

21 Kerkhof M, Droste JHJ, de Monchy JGR, et al. Distribution of total serum IgE and specific IgE to common aeroallergens by sex and age, and their relationship to each other in a random sample of the Dutch general population aged 20-70 years. Allergy 1996;51:770-6.

22 Omenaas E, Bakke P, Elsayed S, et al. Total and specific serum IgE levels in adults: relationship to sex, age and environmental factors. Clin Exp Allergy 1994;24:530-9.
23 Preller L, Zweers T, Brunekreef B, et al. Gezondheidsklachten en klachten over het binnenklimaat in kantoorgebouwen. Den Haag, The Netherlands: DGA, Ministerie van Sociale Zaken, 1990. (In Dutch; Rapport S-83.)

24 Bongers $\mathrm{P}$, Houthuijs $\mathrm{D}$, Remijn $\mathrm{B}$, et al. Lung function and respiratory symptoms in pig farmers. $\mathrm{Br} f$ Ind $\mathrm{Med}$ 1987;44:819-23.

25 Jacobs RR. Airborne endotoxins: an association with occupational lung disease. Appl Ind Hyg 1989;4:50-6.

26 Forster HW, Crook B, Platts BW, et al. Investigation of organic aerosols generated during sugar beet slicing. $\mathrm{Am}$ Ind Hyg Assoc F 1989;50:44-50.

27 Eisen EA, Wegman DH, Louis TA, et al. Healthy worker effect in a longitudinal study of one-second forced expiratory volume $\left(\mathrm{FEV}_{1}\right)$ and chronic exposure to granite dust. Int f Epidemiol 1995;24:1154-62.

28 Broder I, Corey P, Davies G, et al. Longitudinal study of grain elevator and control workers with demonstration of the healthy worker effect. F Occup Med 1985;27:873-80.

29 Choi BCK. Definition, sources, magnitude, effect modifiers, and strategies of reduction of the healthy worker effect. $\mathcal{F}$ Occup Med 1992;10:979-88.

30 Dosman JA, McDuffie HH, Pahwa P. Atopic status as a factor in job decision making in grain workers. 7 Occup $M e d$ 1991;9:1007-10.

31 Grigoreas C, Pappas D, Galatas ID, et al. Serum total IgE levels in a representative sample of a Greek population. Allergy 1993;48:142-6.

\section{Correspondence and editorials}

Occupational and Environmental Medicine welcomes correspondence relating to any of the material appearing in the journal. Results from preliminary or small scale studies may also be published in the correspondence column if this seems appropriate. Letters should be not more than 500 words in length and contain a minimum of references. Tables and figures should be kept to an absolute minimum. Letters are accepted on the understanding that they be subject to editorial revision and shortening.

The journal also publishes editorials which are normally specially commissioned. The Editor welcomes suggestions regarding suitable topics; those wishing to submit an editorial, however, should do so only after discussion with the Editor. 